\title{
CONSIDERATIONS REGARDING THE COMPLIANCE OF ROMANIAN LEGISLATION WITH THE DIRECTIVE (EU) NO. 42/2014 REGARDING THE FREEZING AND CONFISCATION OF THE INSTRUMENTS AND PRODUCTS OF CRIMES COMMITTED IN THE EUROPEAN UNION
}

\section{A. S. Uzlău, C. M. Uzlău}

\section{Andreea Simona Uzlău}

Faculty of legal and administrative sciences, "Dimitrie Cantemir" Christian University of Bucharest

*Correspondence: Universitatea Creştină Dimitrie Cantemir, Splaiul Unirii, nr. 146, sector 4, București, România

E-mail: stoicaandreea76@yahoo.com

\section{Marilena Carmen Uzlău}

Faculty of Economics

"Hyperion" University of Bucharest

*Correspondence: Universitatea Hyperion, Calea Călăraşilor, nr. 169, sector 3, Bucureşti, România

E-mail: carmen_uzlau@yahoo.com

\section{Abstract}

The work analyzes the compliance of domestic legislation with the Directive (EU) $n r$. 42 of April 3, 2014 for the freezing and confiscation of the instruments and products of crimes committed in the European Union, in anticipation of the need to adapt it until the deadline laid down by it, namely October 4, 2016.

Keywords: special confiscation, extended confiscation, the new Criminal Code, the new Code of Criminal Procedure

\section{Introduction}

The study analyzes the compliance of domestic legislation with the Directive (EU) nr. 42 of April 3, 2014 for the freezing and confiscation of the instruments and products of crimes committed in the European Union, in anticipation of the need to adapt it until the deadline laid down by it, namely October 4, 2016.

The analysis is carried out both from the perspective of criminal law and criminal procedure law, and that is structured around the main themes arising from the presentation of this subject, namely the presentation of the Directive, special confiscation, extended confiscation, confiscation of the equivalent expanded into money, confiscation from third persons, specific guarantees in matters of precautionary measures. The study aims to analyze the institution, in order to facilitate the understanding and deepening of the provisions of the Directive to be transposed into our internal legislation.

Presentation of the Directive

The purpose of the Directive (EU) no. 42 of April 3, 2014 for the freezing and confiscation of the instruments and products of crimes committed in the European Union ${ }^{1}$ was strengthening the harmonization of freezing and confiscation of the Member States and to facilitate, in this way, the confidence-building and cross-border cooperation. The time limit

\footnotetext{
${ }^{1}$ Published in the Official Journal of the European Union no. L 127 of 29 April 2014, in force since May 19, 2014.
} 
within which the measures provided by the Directive should be transposed into Romanian legislation is October 4, 2016.

In this sense, the preamble of the directive indicates that organized criminal groups activity is not limited by borders, these groups acquiring more and more goods in Member States other than those in which they are established, as well as in third countries. Therefore, the competent authorities should be provided with the means to identify, freeze, seize and manage products resulted from the committing of offences of this kind.

The directive aims at reviewing and extending the provisions of framework decision 2001/500/JHA of money laundering Council, the identification, tracing, freezing, seizing and confiscation of instrumentalities and products of the crime and the proceeds of framework decision 2005/212/JHA of confiscation of the instrumentalities and property in connection with the crime Council.

By issuing this directive it is aimed to achieve the following specific objectives:

-increasing harmonization of the rules allowing confiscation of products from committing offences, with respect for fundamental rights;

- development of harmonized minimum rules to allow Member States to freeze or seize products from committing crimes in order to subsequent confiscation in accordance with fundamental rights;

- facilitating the seizing, freezing, and cross-border confiscation of goods by Member States;

- increase of instruments that allow freezing and confiscation by the authorities of the Member States, studies showing that, although covered by Union legislation and provided by national legislation, the procedures for confiscation remain insufficiently used.

The directive lays down minimum standards for Member States with regard to the freezing and confiscation of assets deriving from committing crimes by applying direct confiscation, confiscation of the equivalent value, extended confiscation, confiscation which does not rely on a sentence of condemnation and confiscation from third parties (the confiscation from third part).

As regards the direct confiscation, the directive provides that Member States shall take the necessary measures to enable the confiscation, in whole or in part, of the instruments and of the products or goods, the value of which corresponds to such instruments or products, conditioned by the existence of a definitive conviction for an offence which may result in the following of proceedings in absentia [article 4 para. (1)], and, if the confiscation pursuant to paragraph 1 is not possible, at least when such impossibility is the result of disease or of the circumvention of the person suspected or blamed, Member States should take the necessary measures to enable the confiscation of the instruments and in cases where criminal proceedings have been initiated with respect to an offence which is liable to give rise to, directly or indirectly, the economic benefits of such a procedure could result in a judgment of conviction if the person suspected or blamed could appear to the Court [art. 4 paragraph (2)].

However, in cases of sickness or circumvention, the existence of in absentia procedures in the Member States would be sufficient to comply with this obligation (point 15 of the preamble).

Regarding the extended confiscation, the provisions relating to this measure have been consolidated to ensure an unique minimum standard, which may not be lower than the limit laid down in the framework Decision 2005/212/JHA. Framework Decision 2005/212/JHA provide that Member States may choose between three sets of minimum requirements for application of extended confiscation. As a result, in the process of transposition of the framework decision, Member States have chosen different options that have led to conceptual differences as regards the extended confiscation within national jurisdictions. Precisely these differences of interpretation affect cross-border cooperation in cases of confiscation. Therefore, it is necessary a further harmonization of the provisions relating to extended confiscation through the establishment of an unique minimum standard. 


\section{A. S. Uzlău, C. M. Uzlău}

With regard to the confiscation from third parties, in the preamble of the directive (paragraph 24) it is showed that "the practice whereby a person suspected or blamed transfers goods to a third party aware, in order to avoid confiscation, is common and increasingly more widespread. The current EU legislative framework does not contain binding rules concerning confiscation of property transferred to third parties. Therefore, the need to enable the confiscation of property transferred to third parties or purchased by them is becoming ever more marked. The acquisition by a third party refers to situations where, for example, the goods were acquired, directly or indirectly, for example through an intermediary, by the third party from a person suspected or blamed, including when the crime was committed on his behalf or for his benefit, where the person blamed has no assets that can be seized. Such seizure should be possible at least in cases where third parties knew or should have known that the purpose of the transfer or acquisition was to avoid forfeiture, on the basis of facts and specific circumstances, including the fact that the transfer took place free of charge or in return for a sum of money, significantly shorter than the market value of the goods. Rules concerning confiscation applied to third parties should regard to both individuals and legal entities. In any case, it should not prejudice the rights of third parties in good faith."

The directive proposes, in the same time, that, without injuring the different legal systems and framework Decision 2003/577/JHA, to harmonize some aspects of national systems for the freeze with the purpose of confiscation. In this sense, the preamble of the directive indicates that persons suspected or blamed hide assets throughout the entire criminal proceeding. Thus, decisions of confiscation cannot be executed, the persons who are the subject of the decisions of confiscation following to benefit from their belongings after the execution of the penalty. Therefore, it is necessary to be able to determine the exact size of the assets to be covered by the measure of confiscation, even after delivery of a judgment of conviction for an offence, in order to allow full implementation of the decisions of seizure when initially were not identified goods or goods have been found insufficient and judgment of confiscation remains unfulfilled. Assets frozen in a possible subsequent confiscation should be managed properly in order not to lose the economic value. Member States should take the necessary measures, including the ability to sell or transfer the goods to reduce these losses. Member States should take appropriate measures such as, for example, the establishment of national centralized offices to manage property or the establishment of specialized offices or equivalent mechanisms to manage effectively assets frozen prior to confiscation and to preserve their value, pending a decision of the Court (section 32).

The directive provides for specific guarantees and possibilities of appeal in matters of seizure, to ensure an equivalent level of protection and respect of fundamental rights (article 8). These include the right to be informed of the procedures, the right to be represented by an attorney, an obligation to communicate as soon as possible any decision likely to affect property rights and effective opportunity to challenge such a decision. These specific paths are not provided only to persons accused or suspected of committing crimes, but also for other people, in the context of the seizure applied to third parties. The purpose of the freezing of assets is, inter alia, to allow the person affected to challenge the order. Therefore, such a communication should indicate, at least briefly, the reason or reasons of the order concerned, such an indication being possible to be very brief.

\section{Analysis of conformity of national legislation with the directive}

As a legal instrument chosen, the directive leaves Member States the liberty to choose the means of implementing the provisions of the Community act in question.

The directive lays down minimum standards for Member States regarding the application of the direct confiscation, equivalent value confiscation, extended seizure, confiscation which is not based on a sentence of condemnation and confiscation from third parties (the confiscation from third part).

The Romanian penal code, approved by law No. 286/2009, with subsequent amendments and additions, entered into force on February 1, 2014, covers as safety measures 
the direct confiscation, confiscation of the equivalent value, extended confiscation, as well as some cases of confiscation from third parties.

\section{Direct confiscation}

As regards the direct confiscation, the directive provides that such measure can be ordered with the condition to be a definitive conviction for an offence which may result following some proceedings in absentia. The criminal procedure code provides for the possibility of conviction of a person who fails to appear at trial.

In paragraph 15 of the preamble of the directive it is indicated that, if the confiscation is not possible on the basis of a final judgment of conviction, it should be possible, under certain conditions, the confiscation of the instruments and products, at least in cases of sickness or circumvention of the person suspected or blamed. However, in cases of sickness or circumvention, the existence of in absentia procedures in the Member States would be sufficient for compliance with this obligation.

Unlike the previous criminal code, the new penal code allows for all classes of goods indicated in art. 112 paragraph (1) to be subject to special confiscation if an unjustified act provided for in the criminal law has been committed, even if it is not attributable to the person. In the previous penal code, special confiscation was not possible in the case of goods that have been used in committing a criminal act if it did not constitute an offence [art. 118 para. (1) let. b)]. The same situation was for the goods produced, modified or adapted for the purpose of committing any criminal offences [art. 118 para. (1) let. c)].

An absolute novelty for our law system is the arrangement of the confiscation measure, although in the process it has not been pronounced a judgment of conviction, whereas the person suspected or blamed is ill.

Even if from the text of the directive it follows that, if the confiscation is possible, in the laws of the Member States, on the basis of a final judgment of conviction, handed down in absentia, it is no longer necessary for Member States to adopt measures to enable the confiscation in the situation where, although criminal proceedings have been initiated it is not the case, however, for the delivery of a judgment of conviction as the person suspected or blamed is ill, it appears, however, that the rule of the penal code which allows the judgment in absentia does not apply also where the criminal trial cannot proceed on the ground that the person investigated suffers from a disease that prevents him from taking part in the proceedings.

Thus, according to art. 312 para. (1) of the new Code of criminal procedure, in cases where it is found by a forensic investigation that the suspect or the defendant is suffering from a serious illness, which prevents him from taking part in criminal proceedings, the criminal investigation body shall submit its proposals to the Prosecutor together with the file, in order to suspend the prosecution.

In these conditions, until the cessation of the cause that led to the suspension of the prosecution, it cannot be disposed the sending to Court in order to arrive at a conviction.

It should be noted, however, that although prosecution is suspended, this measure is temporary, and the length of it does not enter into the calculation of the limitation period for criminal liability.

Similar measures are laid down for the judgment period. Thus, according to art. 367 para. (1) of the new Code of criminal procedure, „when it is ascertained on the basis of forensic expertise that the defendant suffers from a serious illness, which prevents him from participating in the judgment, the Court orders, through the closing, the suspension of judgment until the state of health of the accused will allow him to participate to the trial".

From the above considerations it follows that in a situation where the prosecution or judgment is suspended, at the end of the case which has resulted in taking this measure, the criminal proceedings should be resumed from the phase in which it was suspended, and if it is 


\section{A. S. Uzlău, C. M. Uzlău}

found that there are conditions of existence of an offence and it was committed by the defendant, there will be pronounced a judgment of conviction.

Having in regard the irrevocability of the confiscation, and the fact that the ground under which prosecution will be suspended is an objective one that cannot be attributed to the accused, the suspension having a fixed-term, we appreciate that in these circumstances there is no need for a regulatory intervention.

However, it is found that the in the current rules of the Code of criminal procedure it is not regulated the possibility of continuing criminal trial under the assumption of the death of the accused, not even for special or extended confiscation.

\section{Confiscation of the equivalent in money}

In this respect, the provisions of the directive converge with the current concept of Romanian legislator regarding confiscation based on a sentence of condemnation. With reference to this aspect, in the preamble of the directive is showed that the Member States are free to define the confiscation of assets of equivalent value as an ancillary or alternative direct confiscation, where appropriate, in accordance with national law.

According to the article. 112 paragraph (5) of the new Criminal Code, ,if the goods subject to confiscation pursuant to paragraph (1) let. b)-(e) are not found, it shall be forfeited money and goods up to their value, instead". At the same time, paragraph (3) of the same article establishes that ,in cases referred to in paragraph (1) let. b) and c), if assets cannot be seized, because they do not belong to the offender and the person to whom they belong to has not known the purpose of their use, it will forfeit their equivalent in money (...). ,,

\section{Extended confiscation}

Extended confiscation is forced and free passage in State ownership of certain things, which belong to the person who has committed a crime, because of their origin from the criminal activities of the same nature, carried out by that person, constantly, over a certain period of time, prior to the offence for which the person is sentenced. ${ }^{2}$

This institution has been incorporated into Romanian legislation by Law no. 63/2012 for the modification and completion of the Penal Code of Romania and of the Law no. 286/2009 relating to the Penal Code, law which transposed into national legislation the article. 3 of framework Decision 2005/212/JHA of 24 February 2005 on confiscation of the products, instrumentalities and goods in connection with the crime.

a) In terms of the length in time for the analysis of the meeting of requirements laid down by national legislation for the implementation of extended confiscation, it should be noted that framework Decision 2005/212/JHA provides that Member States may choose between three sets of minimum requirements for application of extended confiscation, as referred to in art. 3 paragraphs (2) let. a), b) and c). Letter (a) relates to goods that come from activities performed in a period prior to conviction, while letter (b) relates to goods coming from ,similar" activities. With regard to letter (c), it is about the disproportion between the amount/value of the goods and the level of legal income of the person convicted.

The Romanian legislator has opted for the combination of the criteria referred to in letters a) and c). Thus, according to art. $112^{1}$ para. (2) let. a) and b) of the new Criminal Code, extended confiscation shall be ordered, if the value of the property acquired by the person convicted, over a period of 5 years before and, if necessary, after the committal of the crime, until the date of issue of the document instituting the proceedings, clearly exceeds the income on legitimate basis" and ,the Court strongly believes that the goods in question come from the criminal activities of the nature of those referred to in paragraph (1)".

The Directive simplifies the existing system of options in the field of extended confiscation, by providing a common minimum standard, being eliminated one of the criteria

2 N.E. Buzatu, A. Uzlău, Novelties in Security Measures - the Extended Seizure, AGORA International Journal of Juridical Sciences no 3/2013, AGORA University Press, Oradea, p. 19. 
under which goods could be seized, namely the condition that the goods concerned to come from "similar" activities.

It appears, therefore, that by conditioning by the Romanian legislator the enforcement of the safety measure of confiscation by the cumulative performance of the two criteria mentioned above, the regulatory requirements imposed by the Directive 42/2014 regarding freezing and confiscation of the instruments and products of the crimes committed in the European Union are fulfilled.

b) As regards the goods covered by the extended confiscation, it is found that the Romanian legislator did not apply the extended confiscation measure conditional on fulfillment of the requirement that it should come from similar activities, but the Court must be convinced that the goods in question come from the criminal activities of the nature referred to in art. $112^{1}$ para. (1).

In the text of articles. $112^{1}$ para. (2) of the new criminal code it is not imposed the condition that the goods come from similar criminal activities for which he was convicted.

c) In terms of the types of offences for which it may order the confiscation, the difference between regulating the institution of the extended confiscation of the Romanian penal code and the institution in the Directive refers to the fact that the rules of the Romanian Penal Code makes the application of the safety measures conditional on a cumulative performance both of the requirements relating to the classification of the crime committed in relation with offences specifically mentioned in the art. $112^{1}$ and of the minimum limit of the penalty prescribed by law for the criminal acts in question.

However, this double conditionality is not found in the table of contents of the directive, art. 5 where are the subject categories of offences for which you can apply extended confiscation measure using two methods to determine, respectively, to list those categories of offences for which confiscation applies to instrumentalities and the establishment of a minimum punishment for a series of offences referred to in more directives and framework decisions, except the case when the tool does not contain a threshold for punishment, where the reference is made to the penalties laid down by national law.

In our opinion, in conjunction of the provision of art. 3 with those of art. 5 of the directive, it follows that, for the crimes mentioned in article 5 para. (2) let. a)-d), the condition regarding the minimum punishment provided by the law should be deleted, this following to be maintained for the offences referred to in letter e) 1st thesis of the same article, if they do not overlap as indictment.

It is therefore necessary to amend the provisions of this article. $112^{1}$ para. (1) of the new Criminal Code under which they are regulated the conditions that must be met in order to be able to order extended confiscation.

\section{Confiscation from third parties}

With regard to confiscation from third parties, it is found that, in the directive, this measure is based on a particular position of the third parties, under the subjective aspect, to the goods or products concerned (notion of bad faith), bearing in mind that taking this action is conditioned by the fact that they know or ought to know that the purpose of the transfer or acquisition was to avoid confiscation, conclusion inferred from a number of elements of fact and factual circumstances.

In this regard, according to art. 6 paragraph (1) of the directive, „Member States shall take the measures necessary to enable the confiscation of goods or other property whose value corresponds to the products that, directly or indirectly, have been transferred by a person suspected or blamed to third parties, or which have been acquired by third parties from a person suspected or blamed, at least in cases in which the parties knew or ought to have known that the purpose of the transfer or acquisition was to avoid confiscation, on the basis of elements of fact and factual circumstances, including the fact that the transfer or acquisition 


\section{A. S. Uzlău, C. M. Uzlău}

took place free of charge or in return for a sum of money, significantly shorter than the market value of the goods."

a) The Romanian Penal Code (new Penal Code) provides two cases of special confiscation applied to third parties, however, by reference to the definition of the offence provided by the directive in article 2 point 1 , it is found that they are different from the situations covered by the directive.

Thus, according to art. 112 paragraph (3) let. b) and c) of the new Criminal Code, there can be subject of special confiscation the goods that have been used, in any manner, or intended to be used in committing a criminal act referred to in penal law, if, belonging to another person, he knew the purpose of their use, namely the goods used, immediately after committing the act, in order to ensure the perpetrator escape or to keep the product obtained, if, belonging to another person, he knew the purpose of their use. The indication of this hypothesis, about the third party who knew the purpose of good's use, covers the situation where, although complicit in perpetrating the deed, the person whose property is the good cannot be criminally accused. ${ }^{3}$

However, under art. 2 paragraph 1 of the directive, product shall mean any economic advantage obtained, directly or indirectly, from committing a crime; it may consist of any type of good, and includes any rollover or transformation of direct products, as well as any valuable benefits.

Therefore, it is about goods produced by committing the offence provided by criminal law and property acquired through perpetration of the offence provided by the criminal law. ${ }^{4}$

The technical solution for the transposition of the directive's provisions governing the confiscation from the third person is the settlement of the cases referred to in articles. 112 let. a) and e) similarly to those referred to in let. b) and c) of the same paragraph and taking account of the factual elements referred to in the directive from which it can be inferred the subjective position of the third party.

b)Taking advantage of the resumption of the discussion of extended confiscation when adopting normative act by which the directive should be transposed, we appreciate that it should be expressly provided that this measure may be applied towards a family member (ascendants and descendants, brothers and sisters, their children, as well as those made through adoption, according to the law, such relatives, the husband and the people who like those established relationships between spouses or between parents and children, where cohabit - art. 177 of the Penal Code) or a legal person to which the condemned person has control. The provision of this possibility would make the safety measure of extended confiscation not to be devoid of content, and thus turn into an illusory measure, by the alienation of the goods concerned by the confiscation. ${ }^{5}$

In legal doctrine, these provisions have received different interpretations, appreciating that also in the situation when the article 249 para. (4) of the Criminal Procedure Code provides that safety measures for the special confiscation or the extended confiscation can be ordered for assets of the suspect or the accused or other persons in whose possession or property the goods to be seized are, however "taking the measure of extended confiscation cannot be disposed against persons other than the person convicted, who did not commit crimes, regardless of the relationship between these and the person of the offender, because criminal law sanctions apply only to persons who have disregarded the rules of criminal law provisions and are also executed by them. Beyond legal considerations, the personality of sanctions principle of criminal law is very important for any system of law, whereas it is

\footnotetext{
3 Corina Voicu, Andreea Simona Uzlău, Georgiana Tudor, V. Văduva, Noul Cod penal. Ghid de aplicare pentru practicieni, Hamangiu Publishing House, Bucharest, 2014, p. 187.

4 In national law, in certain circumstances, receiving, acquiring, transforming an asset or facilitate its recovery, a person who either knew or foresaw in concrete circumstances that it stems from the offences provided for in committing a criminal act constitutes the crime of concealment provided by art. 270 of the new penal code.

5 I. Pascu, Andreea Simona Uzlău, Drept penal. Partea generală, ediţia a III-a, Hamangiu Publishing House, Bucharest, 2013, p. 492.
} 
unnatural as a criminal penalty to be ordered towards people who have had no involvement in committing a crime". 6

Therefore, art. $112^{1}$ should be supplemented by a new paragraph, which should expressly provide for the possibility of extended confiscation and disposal against a family member or a legal person to which the condemned person is in control, to which the person sentenced or, where appropriate, a third party has transferred goods.

\section{Specific guarantees in matters of precautionary measures}

a) In terms of specific guarantees and possibilities of challenging acts of seizure, respectively confiscation of products and instruments of crimes, it is found that the provisions of the Code of criminal procedure correspond, in a great extent, to the provisions of the directive.

From the Code of penal procedure, it appears that the suspect, defendant or any other person concerned is informed of the precautionary measures to be taken, is entitled to appeal against the precautionary measure taken by the Prosecutor or the bringing to fulfillment of it, the right to be assisted by a lawyer and the right to appeal against the way of bringing to fulfillment the precautionary measure taken during preliminary Chamber or judgment. These specific paths are not provided only for persons accused or suspected of committing crimes, but also for other people, in the context of the confiscation applied to third parties.

Thus, art. 250 paragraph (1) of the code of criminal procedure establishes that "against the precautionary measure taken by Prosecutor or against the bringing to fulfillment of it, the suspect or the defendant or any other interested person may make opposition, within 3 days from the date of communication of the Ordinance making the measure or from the date of fulfilling it, at the judge of the rights and freedoms of the Court to which it would return power to judge the cause".

At the same time, according to the provisions of paragraph (6) of the same article, "against the way of bringing to fulfillment the precautionary measure taken by the judge of preliminary Chamber or by the Court, the Prosecutor, the suspect or the defendant or any other interested person may make this opposition at this judge or this Court, within three days from the date of the enforcement of the measure."

In accordance with article 250 paragraph (7) of the Code of criminal procedure, the opposition is solved, in open court, by reasoned closing, with the attendance of the parties, within five days of its registration.

It appears, therefore, that the penal law does not recognize the possibility of contesting the taking precautionary measures during the preliminary Chamber procedure or during judgment.

Thus, if in the course of the prosecution, the suspect, the accused or any other interested person may challenge both taking precautionary measure and the way of bringing it to fulfillment, if the precautionary measure is taken during the procedure of preliminary Chamber or during judgment, the notice of opposition may be just on the way of bringing to fulfillment the precautionary measures. ${ }^{7}$

Precautionary measures may be taken including during the appeal, in which case the closings and judgment handed down are final. Therefore, it is necessary to regulate the possibility to contest separately these closings, as well as possibility to contest precautionary measures taken by the judge of the preliminary Chamber.

b) In terms of the requirement to respect the right to a fair trial, it is found that the present provisions of the Code of criminal procedure governing the procedure on the basis of

\footnotetext{
${ }^{6}$ M. A. Hotca, Neconstituţionalitatea şi inutilitatea dispoziţiilor care reglementează confiscarea extinsă, http://www.juridice.ro.

7 Corina Voicu, Andreea Simona Uzlău, Georgiana Tudor, V. Văduva, Noul Cod de procedură penală. Ghid de aplicare pentru practicieni, Hamangiu Publishing House, Bucharest, 2014, p. 287.
} 


\section{A. S. Uzlău, C. M. Uzlău}

which the confiscation shall be ordered, largely ensures compliance with the provisions of the directive, including in cases where there is confiscation from third parties.

Thus, after the article. 8 para. (6) of the directive establishes that the Member States must adopt the necessary measures to ensure that persons affected by the measures provided for in this directive have the right to an effective remedy and to a fair trial, for the exercise of their rights, in the paragraphs (5) to (7) there are provided certain assurances, as follows: reasons for judgment of confiscation, its communication to the person affected by taking this measure, provision for the effective possibility of the person against whom seizure is willing to attack the decision of seizure before a Court [para. (6)], regulation for people whose goods are affected by a decision of confiscation, of the right to be assisted by a lawyer, for the entire duration of the procedure of confiscation related to determining the products and tools, in order to be able to exercise his rights [para. (7)].

In the new Code of criminal procedure, this measure may be ordered only by a judge, by a reasoned closing, where the Prosecutor has ordered closure or waiving the prosecution and noticed the preliminary Chamber judge for taking this safety measures (art. $549^{1}$ ) or by a decision in first instance. Both the closing referred to in art. $549^{1}$, and judgment by which the cause was solved may be challenged, namely by opposition [art. $549^{1}$ para. (4)] or appeal, ensuring, thus, the compliance with the provisions of the directive, in terms of the requirement to motivate the act ordering the confiscation and the possibility of challenging it.

Rules of the Code of criminal procedure ensures also the respect of other guarantees of a fair trial including the case of confiscation from third parties, namely the possibility of actual participation in the process, including ensuring the right to defense on the basis of the probation material in the file.

a) Under the procedure of confiscation provided for cases of closure or waiving the prosecution, governed by art. $549^{1}$ of the Criminal Procedure Code, it is stipulated that the judge of the preliminary Chamber informs the persons whose rights or legitimate interests may be affected with a copy of the order of the public prosecutor's Office, putting them in consideration that within 10 days from receipt of the communication they may submit written notes [paragraph (2)].

b) The provisions of the Code of criminal procedure governing the first instance judgment shall provide the opportunity for third parties who have in property or possession the goods covered by the confiscation measure, to participate in this process phase and to benefit from the guarantees of the right to defense, including the right to be assisted by a lawyer. In this regard, according to art. 366 para. (3) of the new Code of criminal procedure, ,people whose goods are subject to seizure may be represented by attorney and may formulate demands, raise exceptions and provide closings with respect to confiscation".

c) This right is recognized also at the appeal hearing, art. 409 para. (1) let. f) of the Code of criminal procedure providing that the appeal may be also declared by any legal or natural person whose legitimate rights have been directly injured by a measure or by an act of the Court in respect of provisions that have caused such damage. At the same time, according to paragraph (2) of the same article it is provided that ,for persons referred to in paragraph (1) let. b)-f), the appeal may be declared by the legal representative or by an attorney, and for the culprit, by his husband."

Regulating these issues is likely to ensure the compliance of the provisions of the Criminal Procedure Code with article. 8 para. (8) of the directive providing that, in proceedings referred to in article 5 (extended confiscation, covering also a segment of the confiscation from third parties), the person affected must have the actual opportunity to challenge the circumstances of the case, including the elements of fact and the evidence available on the basis of which the goods in question are treated as goods derived from criminal activities.

Therefore, it is not necessary the intervention of the legislator to regulate a modified procedure for the participation of third parties in the criminal trial, in which to be met the guarantees of a fair trial. However, in order to ensure the effectiveness of transposing the 
CONSIDERATIONS REGARDING THE COMPLIANCE OF ROMANIAN LEGISLATION WITH THE

DIRECTIVE (EU) NO. 42/2014 REGARDING THE FREEZING AND CONFISCATION OF THE

INSTRUMENTS AND PRODUCTS OF CRIMES COMMITTED IN THE EUROPEAN UNION

provisions of the directive in the Romanian law it might be regulated the obligation of quoting people whose goods are likely to be confiscated, even since the beginning of the trial in first instance.

At the same time, being given the complexity of the probation material to be administered for extended confiscation order, as well as the necessity to meet requirements of fair process, it follows to be assessed whether it would not be useful to establish the possibility of disjunction the cause under this aspect and resolution of the case in relation to the confiscation subsequently the settlement on the defendant's guilt, in order to avoid the fulfillment of the limitation period for criminal liability.

\section{Conclusions}

The study analyzes the compliance of domestic legislation with the Directive (EU) no. 42 of April 3, 2014 for the freezing and confiscation of the instruments and products of crimes committed in the European Union, in anticipation of the need to adapt it until the deadline laid down by it, namely October 4, 2016.

The analysis is carried out both from the perspective of criminal law and criminal procedure law. The subject is of current interest both for theoreticians, but especially for law practitioners, being aware of the many problems arising in this matter, in the jurisprudence of the Courts.

Without issuing the claim that through our intercession the theme has been addressed fully, we appreciate that through advanced theoretical considerations we have managed to bring into focus the main issues which will follow from the application of the institutions and to identify possible preferable legislative solutions.

\section{Bibliography}

- Corina Voicu, Andreea Simona Uzlău, Georgiana Tudor, V. Văduva, Noul Cod penal. Ghid de aplicare pentru practicieni, Hamangiu Publishing House, Bucharest, 2014;

- Corina Voicu, Andreea Simona Uzlău, Georgiana Tudor, V. Văduva, Noul Cod de procedură penală. Ghid de aplicare pentru practicieni, Hamangiu Publishing House, Bucharest, 2014;

- N.E. Buzatu, A. Uzlău, Novelties in Security Measures - the Extended Seizure, AGORA International Journal of Juridical Sciences no 3/2013, AGORA University Press, Oradea;

- I. Pascu, Andreea Simona Uzlău, Drept penal. Partea generală, ediţia a III-a, Hamangiu Publishing House, Bucharest, 2013;

- M. A. Hotca, Neconstituţionalitatea şi inutilitatea dispoziţiilor care reglementează confiscarea extinsă, http://www.juridice.ro. ${ }^{8}$ 